\title{
The Effect of Pilates and Low Intensity Cardio Exercise on Insulin Resistance in Women
}

\section{Pilates ve Düşük Şiddetli Kardiyo Egzersizlerinin Kadınlarda İnsülin Direnci Üzerine Etkisi}

\author{
Ömer Mumcu1, Rabia Hürrem Özdurak Sıngın², Faruk Yamaner², Ferit Kerim Küçükler³ \\ ${ }^{1}$ Institute of Health Sciences, Hitit University, Çorum, Turkey \\ ${ }^{2}$ Department of Physical Education and Sports, Faculty of Sports Sciences, Hitit University, Çorum, Turkey \\ ${ }^{3}$ Endocrinology and Metabolic Diseases Clinic, Memornal Ataşehir Hospital, İstanbul, Turkey
}

\section{Ö. Mumcu \\ 0000-0001-9077-4015 \\ R.H. Özdurak Singın (iD 0000-0003-3729-5028 \\ F. Yamaner \\ 0000-0002-2302-8650 \\ F. K. Küçükler \\ 0000-0002-9277-0584}

Geliş Tarihi/Date Received: 07.10.2019

Kabul Tarihi/Date Accepted: 26.12.2019

Yayın Tarihi/Published Online: 25.03.2020

\section{Yazışma Adresi /}

Corresponding Author:

Rabia Hürrem Özdurak Sıngın

Hitit Üniversitesi Spor Bilimleri

Fakültesi , Beden Eğitimi ve

Spor Anabilim Dalı, Çorum, Turkey

E-mail: hurremo@gmail.com

(C2020 Türkiye Spor Hekimleri Derneği. Tüm hakları saklıdır.

\section{ABSTRACT}

Objective: Aim of the study was to determine the effect of pilates and low-intensity cardio-exercise on insulin resistance among women who have developed insulin resistance.

Material and Methods: The study included women with insulin resistance aged 20 to 40 years who neither regularly attend any exercise program nor received any medication for the last six months. A total of 45 volunteer women were equally divided into low-intensity cardio exercise (LICE), pilates exercise (PE) and control (K) groups. Exercise groups received a 60-minute pilates or low-intensity cardio exercise program 3 times a week. Anthropometric measurements of the participants such as height, weight, body mass index, waist and hip circumferences, waist-to-hip ratio as well as blood parameters such as triglyceride (TG), high density lipoprotein (HDL), low density lipoprotein (LDL), total cholesterol (TC), fasting blood glucose (FBG), fasting insulin (FI) and insulin resistance (IR) were measured before and after the 12 week exercise period.

Pre and post-test measurements of the groups were analyzed by Wilcoxon Sign-T test, differences between the groups by Kruskal Wallis $\mathrm{H}$ test, and paired comparisons of the groups were analyzed by Mann Whitney U test using SPSS 18.0 software.

Results: It was found that LICE and PE exercises caused a statistically significant decrease in weight, body mass index, waist and hip circumference, however, there was no statistically significant difference in $\mathrm{C}$ group. It was found that both exercises caused a statistically significant decrease in FBS, FI and IR values. Although LDL $(p=0.04)$ and TC $(p=0.03)$ were decreased in LICE group, they remained almost same in the PE group. After 12 weeks of exercise, there was a statistically significant difference between the groups in terms of $F I$ and IR $(p=0.01)$, but there was no significant difference in fasting blood glucose values. A statistically significant decline in IR $(p=0.04)$ was observed in LICE group when compared to $C$ group.

Conclusion:

LICE program helps to decrease the IR when administered for at least 12 weeks. Pograms should include flexibility and balance impoving exercises such as pilates.

Keywords: Insulin resistance, cardio exercise, pilates.

\section{öz}

Amaç: İnsülin direnci gelişmiş kadınlarda pilates ve düşük şiddetli kardiyo egzersizlerinin insülin direncine etkisini incelemektir. 
Gereç ve Yöntem: Çalışmaya son altı ayda düzenli olarak herhangi bir egzersiz programına katılmamış ve ilaç tedavisi görmeyen, insülin direnci gelişmiş 20-40 yaş aralığında kadınlar dahil edildi. 45 gönüllü kadın eşit olarak düşük şiddetli kardiyo egzersizi (DŞKE), pilates egzersizi (PE) ve kontrol (K) guruplarına ayrıldı. Egzersiz gruplarına haftada 3 gün, bir çalışmada 60 dakikalık pilates veya düşük şiddetli kardiyo egzersiz programı uygulandı. Kadınların 12 haftalık egzersiz uygulaması öncesi ve sonrası kilo, vücut kütle indeksi (VKi), bel ve kalça çevresi, bel-kalça oranı (BKO) gibi antropometrik ölçümlerinin yanı sıra trigliserit (TG), yüksek dansiteli lipoprotein (HDL), düşük dansiteli lipoprotein (LDL), total kolesterol (TC), açlık kan şekeri (AKŞ), açlık insülin (Ai) ve insülin direnci (ID) gibi kan parametreleri ölçüldü. Grupların ön test ve son test ölçümleri Wilcoxon İşaret T testi, gruplar arası farklılıklar Kruskal Wallis $\mathrm{H}$ testi, grupların ikili karşılaştırmaları ise Mann Whitney $\mathrm{U}$ testi kullanılarak SPSS 18.0 programında analiz edildi.

Bulgular: DŞKE ve PE egzersizlerinin kilo, VKi, bel ve kalça çevresinde istatistiksel olarak anlamlı azalmaya neden olduğu, C grubunda ise istatistiksel olarak anlamlı bir fark olmadığı saptandı. Her iki egzersizin AKŞ, Ai ve iD değerlerinde istatistiksel olarak anlamlı bir azalmaya neden olduğu saptandı. LDL $(p=0.04)$ ve TC $(p=0.03)$ seviyelerinin DŞKE gurubunda azaldığı gözlemlenirken, PE gurubunda değişmediği görüldü. 12 haftalık egzersiz sonrasında guruplar arasında Ai ve iD değerlerinde istatistiksel olarak anlamlı bir fark olduğu $(p=0.01)$, AKŞ değerlerinde ise guruplar arasında anlamlı bir fark olmadığı görüldü. K gurubu ile karşılaştırıldığında DŞKE gurubunda iD’nin ( $p=0.04)$ istatistiksel olarak anlamlı düzeyde azaldığı görüldü.

Sonuç: 12 haftalık DŞKE programının ID düzeyini azaltmaya yardımcı olduğu görülmüştür. Programlara esneklik ve dengeyi artıran, pilates gibi destekleyici egzersiz türleri de eklenmelidir.

Anahtar Sözcükler: İnsülin direnci, kardiyo egzersizi, pilates

Available at: http://journalofsportsmedicine.org and http://dx.doi.org/10.5152/tjsm.2020.180

Cite this article as: Mumcu O, Ozdurak Singin RH, Yamaner F, Kucukler FK. The Effect of Pilates and Low Intensity Cardio Exercise on Insulin Resistance in Women. Turk J Sports Med. 2020;55(4):259-66.

\section{GíRiş}

21. yüzyılda artan bir ivmeyle yaygınlaşan sedanter yaşam şekli fiziksel hareketsizliğe bağlı gelişen hastalıklara neden olduğundan çağımızın en önemli sağlık tehdidini oluşturmaktadır (1). Sedanter bir yaşam süren bireylerde fiziksel güçsüzlük gelişmekte, obezite oluşumu ile birlikte insülin direnci (ID), koroner kalp hastalığı, tip 2 diyabet, hipertansiyon ve çeşitli kanser türleri gibi birçok hastalık baş göstermektedir. Dolayısıyla bütün bu faktörler bireylerin yaşam kalitesi ve yaşam süresinin azalmasına neden olmaktadır (2).

İnsülin direnci (ID), pankreas tarafından salınan insülin hormonunun yağ, kas ve karaciğer hücrelerinde bulunan reseptörlerine yeterli miktarda bağlanamaması ve/veya hücrede işlevini yerine getirememesi olarak tanımlanmaktadır. Bunun sonucunda pankreas, kandaki glikoz seviyesini azaltmak için çok fazla insülin üretmeye başlamakta, bu da kandaki insülin seviyesinin artmasina neden olmaktadır (3).

İ’nin gelişmesinde genetik faktörlerin yanı sıra fiziksel inaktivite, sağlıksız beslenme, bazı ilaçlar, sigara ve alkol tüketimi gibi yaşam tarzına bağlı faktörlerin önemli rol oynadığı, yaşlan- manın da İD gelişiminde büyük bir etkisi olduğu kabul edilmektedir (4). ID olan bireylerde hastalığın erken evrelerinde düzenli fiziksel aktivite ve dengeli beslenme büyük önem taşımakta, farmakolojik tedavi çoğunlukla hastalık ilerledikçe tercih edilmektedir $(5,6)$.

Düzenli yapılan fiziksel aktivitenin kalp damar hastalıkları, obezite, tip 2 diyabet, yüksek tansiyon, kolon ve meme kanseri gibi pek çok hastalıktan koruyucu etkisinin yanında tip 2 diyabet, yüksek tansiyon ve obezite gibi hastalıkların tedavisinde de etkili olduğu belirtilmektedir (7). Khoo ve ark. obez erkeklerde diyet ve egzersize bağlı kilo kaybının bel çevresi, İ ve inflamasyon üzerine etkisini karşılaştırmak için 40 hastaya 24 hafta boyunca orta şiddetli aerobik egzersiz, direnç egzersizi ve diyet uygulamış, obez erkeklerde enerji tüketimini arttıran egzersizin İD ve sistemik inflamasyonun tedavisinde diyetten daha etkili olduğunu bildirmiş̧lerdir (8).

Literatürde egzersizin tipi, şiddeti, yoğunluğu ve süresinin vücutta farklı etkiler yarattığı, hatta aynı egzersizin bireylerde yaşa, cinsiyete, sağlık durumuna ve fiziksel uygunluk seviyelerine göre farklı yanıtlar ürettiği gösterilmiştir (9). Özellik- 
le orta yaş döneminde yapılan düzenli egzersizin ileri yaşlarda da fiziksel fonksiyonları üst seviyede sürdürme, metabolik ve kronik hastalıklara yakalanma riskini azaltmada büyük bir etkisi olduğu bildirilmektedir (10). Ayrıca, orta yaş döneminde yapılan düzenli fiziksel aktivitenin, özellikle kadınlarda metabolizmanın yavaşlamasından dolayı alınan aşırı kiloların, obezite ve diyabet gibi hastalıkların önlenmesinde önemli bir rol oynadığı düşünülmektedir (11). Bu nedenle sağlık için egzersiz programı oluşturulurken bireysel farklılıklar göz önünde bulundurulmalı, kişinin fiziksel aktivite düzeyi, yaşı, cinsiyeti, sağlığı, fiziksel ve fizyolojik durumu ile egzersize verdiği yanıtlar dikkate alınarak hedefler belirlenmelidir (12). Özellikle İD gibi mekanizması henüz tam olarak aydınlatılamamış hastalıkların tedavisinde uygulanabilecek farklı egzersiz protokolleri ve/veya hastalığın farklı evrelerinde bulunan hasta gruplarının belirli egzersizlere verdiği yanıtları sorgulayan çalışmalara ihtiyaç duyulmaktadır.

$\mathrm{Bu}$ çalıșmanın amacı insülin direnci gelişmiş 20 ile 40 yaş arası sedanter kadın hastalarda pilates ve düşük şiddetli kardiyo egzersizlerinin etkisini incelemektir.

\section{GEREÇLER VE YÖNTEM}

\section{Örneklem}

Çalışmaya Ankara Numune Eğitim Araștırma Hastanesi Klinik Araştırmalar Etik Kurulu'nun E-19-2675 tarih ve sayll izni ile Endokrinoloji ve Metabolizma Hastalıkları Kliniği'ne bașvuran 20-40 yaș aralığında kadınlar arasından insülin direnci (ID) gelişmiş (HOMA-IR > 2.7), son 6 ay içerisinde düzenli olarak herhangi bir egzersiz programına katılmayan ve ilaç tedavisi almamış toplam 45 gönüllü dahil edildi. Metabolik sendrom, tip 2 diyabet, yüksek tansiyon, kardiyovasküler veya pulmoner rahatsızlığı bulunan veya egzersiz yapmasina engel herhangi bir durumu olan kadınlar çalışmaya alınmadı. Gönüllük esasına göre seçilen kadınlar kendi istekleri doğrultusunda pilates egzersizi (PE), düşük yoğunluklu kardiyo egzersizi (DYKE) veya kontrol (K) olmak üzere 15 kişilik gruplara ayrıldı.

\section{Uygulanan Egzersiz Programları}

$P E$ ve DŞKE gruplarına haftada 3 gün ve günde $60 \mathrm{dk}$ olmak üzere 12 hafta boyunca spor salonunda ve hemşire gözetiminde aynı egzersiz uzmanı tarafından program uygulanırken, kontrol grubuna herhangi bir egzersiz yaptırılmadı. Egzersiz seansları her iki grupta da kalp atım hızı 140 nabız/dk'yı geçmeyecek şekilde $10 \mathrm{dk}$ ısınma, $45 \mathrm{dk}$ asıl evre ve $5 \mathrm{dk}$ da soğuma şeklinde planland.

PE grubunda egzersizler ilk 4 hafta $2 \times 8$ (set $\mathrm{x}$ tekrar), 4 ile 8 . hafta arası $3 \times 10,8$ ile 12. hafta arasında ise $4 \times 12$ olacak şekilde kademeli olarak arttırıldı. DŞKE grubuna koşu bandında (Precor TRM 932i, Canada) koş-yürü şeklinde egzersiz yaptırıldı. Egzersizin şiddeti Karvonen Metodu'na göre belirlendi ve kademeli olarak arttırıldı (13).

Antropometrik ölçümler: Egzersiz programına başlamadan 1 hafta önce ve bitiminden 1 hafta sonra boy, kilo, vücut kütle indeksi (VKİ), bel ve kalça çevresi ölçümleri yapıldı. Boy uzunluğu 1 $\mathrm{mm}$ hassasiyetli Duvara monte stadiometre ile ayaklar çıplak ve yere düz olarak basarken, topuklar bitişik, dizler gergin ve vücudun dorsal kısmı duvara değecek şekilde dik pozisyonda ve frankfort düzlemine dikkat edilerek ölçüldü. Katılımcıların vücut ağırlığı ölçümleri çıplak ayak ve hafif giysi ile hassaslık derecesi $0.01 \mathrm{~kg}$ olan baskül (Seca, Germany) ile yapıldı. VKI'nin belirlenmesinde; vücut ağırlığının boy uzunluğunun karesine bölünmesi $\left(\mathrm{kg} / \mathrm{m}^{2}\right)$ formülü kullanıldı (11). Bel çevresi subkostal bölge ile krista iliaka arasındaki en dar bölgeden yere paralel olacak şekilde, kalça çevresi ise her iki kalçanın en geniş çıkıntısını içine alacak şekilde ölçüldü ve bel kalça oranı (BKO) hesaplandı (14).

Kan Parametreleri: Tüm katılımcıların kan örnekleri hastanenin kan alma biriminde aynı flebotomist tarafından 8-10 saatlik gece açlığı sonrası 10 cc tüplere alındı. İnsülin (İ), açlık kan şekeri (AKŞ) ölçümleri ultra duyarlı insülin kiti kullanılarak UniCel DxC 800 System (Beckman Coulter Inc. USA) cihazında, trigliserit (TG), yüksek dansiteli lipoprotein (HDL), düșük dansiteli lipoprotein (LDL), total kolesterol (TK) ölçümle- 
ri ise Olympus AU 2700 (Beckman Coulter Inc. USA) cihazında gerçekleștirildi.

İnsülin direncinin belirlenmesi: İD’nin hesaplanmasında HOMA-IR formülü (HOMA-IR= açlık insülin değeri $(\mu \mathrm{IU} / \mathrm{mL}) \mathrm{x}$ açlık glikoz seviyesi (mg/dL) /405) kullanıldı. HOMA-IR>2.7 olması insülin direnci olarak kabul edildi (15).

\section{İstatistiksel Analiz}

Verilerin istatistiksel analizi PASW Statistics for Windows (Version 18.0, Chicago: SPSS Inc.) paket programı kullanılarak yapıldı. Veri setinin normal dağılımı Shapiro-Wilks ve KolmogorovSmirnov testleri ile sinand. Nicel verilerin analizinde betimsel istatistik kullanıldı, sonuçlar ortalama \pm standart sapma olarak sunuldu. Grupların ön test ve son test değerleri Wilcoxon İşaret $\mathrm{T}$ testi, gruplar arası farklar Kruskal-
Wallis $\mathrm{H}$ testi, grupların ikili karşılaștırmaları ise Mann Whitney U testi kullanılarak analiz edildi.

\section{BULGULAR}

Ön test verileri kullanılarak yapılan gruplar arası karşılaştırmalarda yaş, boy, ağırlık, VKİ, bel çevresi, kalça çevresi ve BKO değişkenlerinde istatistiksel olarak anlamlı bir fark bulunmadı. Kan parametrelerinden TG, TK, HDL, LDL, AKŞ, Aİ ve İD değerleri incelendiğinde gruplar arasında istatistiksel olarak anlamlı bir fark olmadığı gözlendi.

Her bir grup için ön test ve son test sonuçları karşılaştırıldığında PE ve DŞKE gruplarında kilo, VKİ, bel çevresi, kalça çevresi ve BKO değişkenlerinde istatistiksel olarak anlaml bir azalma olduğu saptanırken $(\mathrm{p}<0.05), \mathrm{K}$ grubunda istatistiksel olarak anlamlı bir fark bulunmadı ( $p>0.05$ ) (Tablo 1).

Tablo 1. Tüm grupların egzersiz öncesi ve egzersiz sonrası antropometrik ölçümlerin ön test-son test karşılaştırması.

\begin{tabular}{|c|c|c|c|c|c|c|}
\hline & $\begin{array}{c}\text { PE }(n=15) \\
\bar{x} \pm s S\end{array}$ & $p$ & $\begin{array}{c}\text { DŞKE }(n=15) \\
\bar{x} \pm s S\end{array}$ & $p$ & $\begin{array}{c}\text { K (n=15) } \\
\overline{\mathbf{x}} \pm s s\end{array}$ & $p$ \\
\hline Yaş (yıl) & $29.2 \pm 5.3$ & & $29.3 \pm 5.9$ & & $29.1 \pm 5.6$ & \\
\hline Boy $(\mathrm{cm})$ & $161.5 \pm 20.3$ & & $160.9 \pm 2.4$ & & $160.9 \pm 2.3$ & \\
\hline \multicolumn{7}{|l|}{ Kilo (kg) } \\
\hline $\begin{array}{l}\text { E.Ö. } \\
\text { E.S. }\end{array}$ & $\begin{array}{l}93.6 \pm 22.5 \\
90.8 \pm 20.5\end{array}$ & $0.03 *$ & $\begin{array}{l}95.7 \pm 20.1 \\
88.7 \pm 18.9\end{array}$ & $0.01^{*}$ & $\begin{array}{c}99.6 \pm 19.9 \\
100.3 \pm 20.2\end{array}$ & 0.14 \\
\hline \multicolumn{7}{|c|}{ VKİ (kg/m²) } \\
\hline $\begin{array}{l}\text { E.Ö. } \\
\text { E.S. }\end{array}$ & $\begin{array}{l}36.2 \pm 7.1 \\
35.4 \pm 6.7\end{array}$ & $0.04^{*}$ & $\begin{array}{l}36.8 \pm 6.8 \\
34.4 \pm 6.3\end{array}$ & $0.01^{*}$ & $\begin{array}{l}36.9 \pm 7.7 \\
37.1 \pm 7.8\end{array}$ & 0.32 \\
\hline \multicolumn{7}{|c|}{ Bel çevresi (cm) } \\
\hline $\begin{array}{l}\text { E.Ö. } \\
\text { E.S. }\end{array}$ & $\begin{array}{l}104.1 \pm 12.7 \\
101.5 \pm 13.2\end{array}$ & $0.04^{*}$ & $\begin{array}{c}107.4 \pm 14.2 \\
97.9 \pm 13.6\end{array}$ & $0.01^{*}$ & $\begin{array}{l}109.9 \pm 14.9 \\
110.0 \pm 15.7\end{array}$ & 0.10 \\
\hline \multicolumn{7}{|c|}{ Kalça çevresi (cm) } \\
\hline $\begin{array}{l}\text { E.Ö. } \\
\text { E.S. }\end{array}$ & $\begin{array}{l}121.2 \pm 13.5 \\
117.3 \pm 13.8\end{array}$ & $0.01^{*}$ & $\begin{array}{l}123.0 \pm 13.9 \\
115.2 \pm 13.8\end{array}$ & $0.01^{*}$ & $\begin{array}{l}121.3 \pm 13.5 \\
121.9 \pm 13.8\end{array}$ & 0.15 \\
\hline \multicolumn{7}{|c|}{ Bel/Kalça Oranı } \\
\hline $\begin{array}{l}\text { E.Ö. } \\
\text { E.S. }\end{array}$ & $\begin{array}{l}0.9 \pm 0.1 \\
0.8 \pm 0.1\end{array}$ & $0.03^{*}$ & $\begin{array}{l}0.9 \pm 0.1 \\
0.8 \pm 0.1\end{array}$ & $0.02^{*}$ & $\begin{array}{l}0.9 \pm 0.1 \\
0.9 \pm 0.1\end{array}$ & 0.22 \\
\hline
\end{tabular}

PE: Pilates Egzersizi, DŞKE: Düşük Şiddetli Kardiyo Egzersizi, K: Kontrol, EÖ: Egzersiz Öncesi, ES: Egzersiz Sonrası. ${ }^{*} p<0.05$ seviyesinde istatistiksel olarak anlamll.

Ön test ve son test kan parametreleri karşılaştırıldığında PE grubunda AKŞ ( $\mathrm{p}=0.01)$, Aİ $(p=0.01)$ ve İ'inde $(p=0.01)$ anlaml bir azalma gözlemlenirken, TG, TK, LDL, HDL değerlerinde istatiksel olarak anlamlı bir fark bulunmadı ( $p>0.05)$. Öte yandan DŞKE grubunda TK $(\mathrm{p}=0.03), \quad$ LDL $(\mathrm{p}=0.04)$, AKŞ $(\mathrm{p}=0.01)$, AI $(\mathrm{p}=0.01)$ ve İD'nde $(\mathrm{p}=0.01)$ anlamlı bir azalma görülürken, TG ve HDL değerlerinde istatistiksel olarak anlamlı bir fark bulunmadı ( $\mathrm{p}>0.05)$. K grubunun kan parametrelerinde de istatistiksel olarak anlamlı bir fark bulunmadı (Tablo 2). 
Tablo 2: Tüm gruplarının egzersiz öncesi ve egzersiz sonrası kan parametrelerinin ön test- son test karşılaştırması.

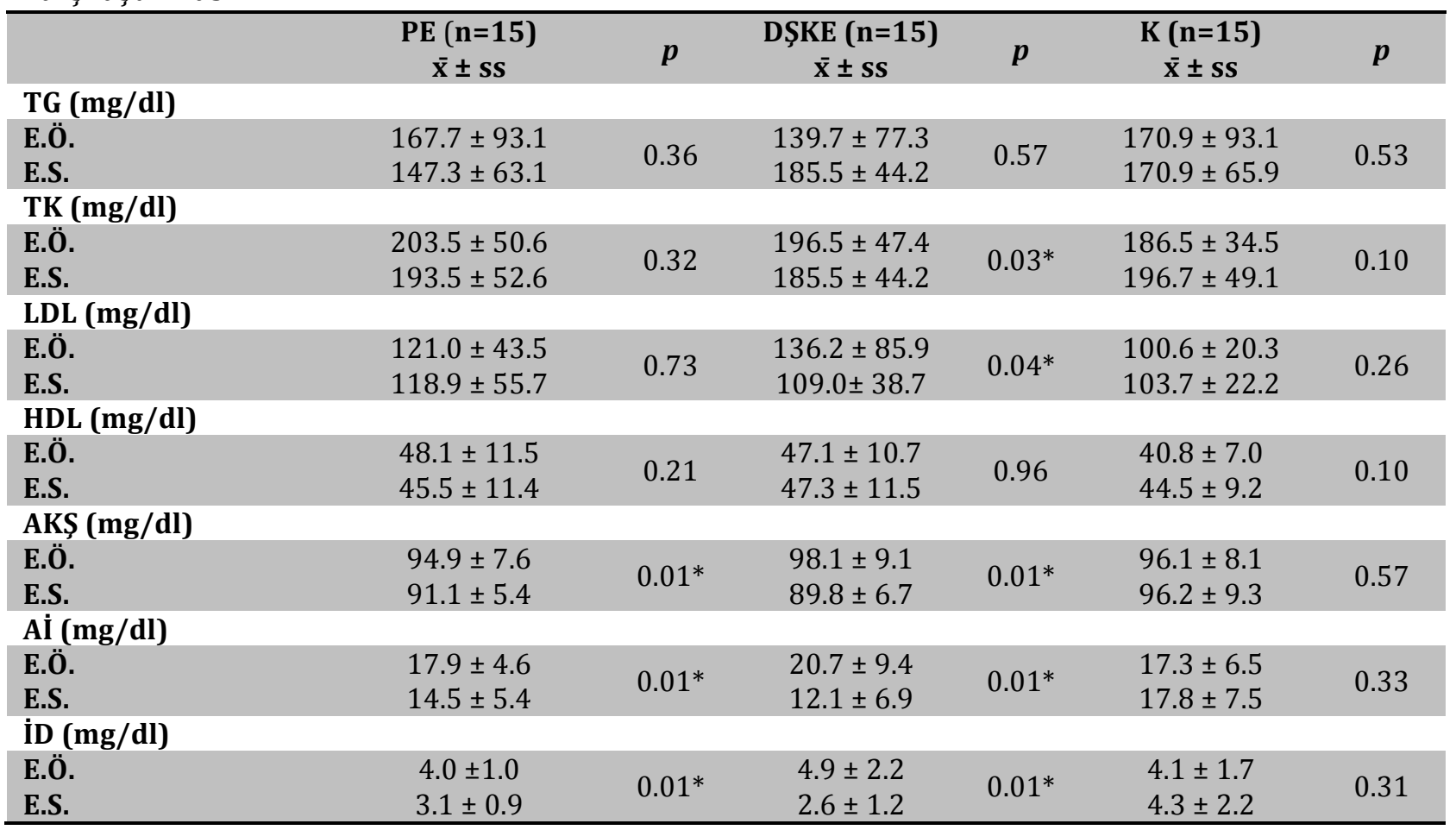

PE: Pilates Egzersizi, DŞKE: Düşük Şiddetli Kardiyo Egzersizi, K: Kontrol, TG: Trigliserit, TK: Total Kolestrol, LDL: Düşük Dansiteli Lipoprotein, HDL: Yüksek Dansiteli Lipoprotein, AKŞ: Açlık Kan Şekeri, Aİ: Açlık İnsülini, ID: İnsülin Direnci. *p<0.05 seviyesinde istatistiksel olarak anlaml.

Son test verileri kullanılarak yapılan Kruskal Wallis-H test sonucunda gruplar arasında Aİ $\left(\mathrm{x}^{2}\right.$ $=13.1 ; \mathrm{p}=0.01)$ ve İD $\left(\mathrm{x}^{2}=14.1 ; \mathrm{p}=0.01\right)$ değerlerinde istatistiksel olarak anlamlı bir fark oldu$\breve{g u}$, ancak AKŞ ( $\left.x^{2}=3.5 ; p=0.17\right)$ için anlamlı dü-

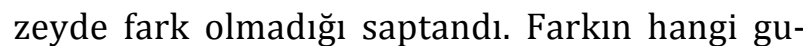
ruplardan kaynaklandığını belirlemek üzere yapılan ikili karşılaştırmalarda farkın DŞKE ile K gurubu arasında ve DŞKE gurubu lehine gerçekleştiği $(\mathrm{z}=-1.6 ; \mathrm{p}=0.04)$ görüldü (Tablo 3 ).

Tablo 3: Egzersiz sonrası gruplar arası açlık insülin ve insülin direnci değerlerinin ikili karşılaștırması.

\begin{tabular}{|c|c|c|c|c|c|}
\hline & & $\bar{n}$ & $\overline{\overline{\mathbf{x}}}$ & $\overline{\mathbf{x}}_{1}-\overline{\mathbf{x}}_{2}$ & $P$ \\
\hline \multirow[t]{6}{*}{ AI } & DŞKE & 15 & 12.1 & -2.4 & 0.66 \\
\hline & PE & 15 & 14.5 & & \\
\hline & PE & 15 & 14.5 & -3.3 & 0.45 \\
\hline & $\mathrm{K}$ & 15 & 17.8 & & \\
\hline & DŞKE & 15 & 12.1 & -5.6 & 0.12 \\
\hline & $\mathrm{K}$ & 15 & 17.8 & & \\
\hline \multirow[t]{6}{*}{ İD } & DŞKE & 15 & 2.6 & -0.4 & 0.63 \\
\hline & PE & 15 & 3.1 & & \\
\hline & PE & 15 & 3.1 & -1.2 & 0.18 \\
\hline & $\mathrm{K}$ & 15 & 4.3 & & \\
\hline & DŞKE & 15 & 2.6 & -1.6 & $0.04^{*}$ \\
\hline & $\mathrm{K}$ & 15 & 4.3 & & \\
\hline
\end{tabular}

PE: Pilates Egzersizi, DŞKE: Düşük Şiddetli Kardiyo Egzersizi, K: Kontrol, Aİ: Açlık İnsülini, İD: İnsülin Direnci. ${ }^{*} p<0.05$ seviyesinde istatistiksel olarak anlaml. 


\section{TARTIŞMA}

Egzersiz öncesi ve sonrası antropometrik veriler incelendiğinde düzenli egzersizin kilo, VKİ, bel çevresi, kalça çevresi ve BKO'da anlamlı bir azalmaya neden olduğu açıkça görülmektedir. K grubu ile karşılaştırıldığında PE ve DŞKE'nin kadınlarda kilo kaybı ve bölgesel incelme yönünde etkili olduğu görüldü. Ayrıca $P E$ ve DŞKE'nin kısa dönemde AKŞ, Aİ ve İD'yi azalttığı saptandı. $\mathrm{Bu}$ çalışmanın sonuçları erkeklerin değerlendirildiği çalışmalar ile paralellik göstermektedir. Motahari-Tabari ve ark. tip 2 diyabet hastalarına 8 hafta boyunca haftada $3 \mathrm{kez}$ uygulanan aerobik egzersizin BKO, VKİ, AKŞ, AI ve İD üzerine olumlu etkileri olduğunu bildirmişlerdir (16).

Huffman ve ark. ise orta yaşl, hafif kilolu veya obez, tip 2 diyabet riski taşıyan bireylerde aerobik egzersizin insülin duyarlılığı, metabolik parametreler ve hormonlar üzerinde olumlu etkisinin egzersize başladıktan 15 gün sonra başladığını ileri sürmüşlerdir (17).

Elde edilen verilerin ışığında, PE ve DŞKE'nin kilo kontrolü, AKȘ ve Aİ değerlerinin düzenlenmesinde, egzersiz tipinin ise kan lipid parametreleri üzerinde etkili olduğu dikkat çekmektedir. Bulgulara göre DŞKE gurubunda 12 haftalık egzersiz sonrasında TK ve LDL değerlerinin azaldığı, PE'nin ise TK ve LDL değerlerini düşürmeye yeterli olmadı̆̆ı görüldü (Tablo 2). DŞKE grubunda egzersiz sonrasında LDL seviyesinin $136.67 \mathrm{mg} / \mathrm{dL}$ seviyesinden 12 haftalık egzersiz uygulaması sonunda normal sinırlar içinde kabul edilen $108.90 \mathrm{mg} / \mathrm{dL}$ seviyesine gerilediği saptandı. Yüksek LDL ve kolesterol seviyeleri damarların zamanla sertleşmesine ve elastikiyetini kaybetmesine yol açarak dolaşım bozukluklarına, damar tıkanıklığına bağlı gelişebilecek kardiyovasküler rahatsızlıklara, hipertansiyon, emboli, felç, böbrek yetmezliği ve kalp krizi gibi mortalite riski yüksek sağlık problemlerine neden olabilmektedir (18). LDL ve kolesterolün yükselmesi en çok kalp ve beyni besleyen damarları etkilediğinden oldukça önemli bir risk faktörü olarak algılanmalıdır.

Egzersizin tipi çalıştırdığı kas grupları ve vücutta yarattı̆̆ ve süresi kadar önemli bir parametredir. Pilates, özellikle "core" olarak adlandırılan gövde ve iskeletimizi ayakta tutan büyük kas gruplarını güçlendirmeye yardımcı olurken aynı zamanda esnekliği ve dengeyi geliştirmektedir. Oysa koşma, bisiklete binme, yüzme ve kürek çekme gibi kardiyo egzersizleri fiziksel kondisyonu iyileştirmenin yanında bedeni sürekli hareket halinde tutarak kalp atışlarını uzun süre normal seviyenin üzerinde tutmayl hedeflemektedir. ACSM (American College of Sports MedicineAmerikan Spor Hekimliği Koleji), erişkin bireylerin haftalık $150 \mathrm{dk}$ orta veya $75 \mathrm{dk}$ yüksek şiddetli kardiyo egzersizleri yaparak kardiyovasküler fonksiyonlarını iyileştirebileceğini hatta kardiyo egzersizlerinin kilo vermede en etkili egzersiz şekli olduğunu savunmaktadır (12).

Literatürde her türlü egzersizin insülin duyarlılığını arttırdığı hayvan çalışmalarıyla kanıtlanmıştır (19). Düzenli ve yüksek şiddetli egzersiz yapan kişilerin doku insülin hassasiyetlerinin arttı̆̆ AKŞ, Aİ ve İD’nin egzersiz öncesi ve sonrası değerleri ele alındığında, PE ve DŞKE'nin 12 haftada etki gösterdiği saptandı. Guruplar arası ikili karşılaştırmalarda ise DŞKE gurubunda $\mathrm{K}$ grubu ile karşılaştırıldığında İD'de azalma olduğu saptandı. Bulgulara göre DŞKE'nin İD’yi düşürdüğü, ancak PE'nin ID'de istatistiksel olarak anlamlı bir fark yaratmadığı gözlendi (Tablo 3). Literatürde fiziksel aktivite ve yaşam tarzı değişikliklerinin İD'yi azalttığını gösteren çalışmalar bulunmakla birlikte (20), yapılan egzersizin şiddeti ve tipinin İD’yi düşürmedeki etkisinin de irdelenmesi gerekmektedir. 60 dakikalık direnç egzersizi ile \%80-90 şiddetindeki interval egzersizlerin obezite hastalığı tanısı almış sedanter erkeklerde ID ve Aİ seviyelerini azalttığı bildirilmiştir (21). Çalışmada Aİ düzeyinin egzersizden etkilenmemiş olması yapılan egzersizlerin şiddetinin düşük olması ile ilgili olabilir. Bunun yanı sıra egzersiz şiddeti kadar egzersiz tipinin de İD'nin düşmesinde önemli bir rol oynadığl, hatta aynı şiddetteki egzersizlerin bile farklı etkileri olabileceği unutulmamalıdır. Literatürde özellikle aerobik ve direnç egzersizlerinin kan glikoz düzeyinin düzenlenmesinde etkili olduğu ve her yaştaki bireylerin yapılandırılmış bir eg- 
zersiz programına dahil edilerek sinerjik bir etki sağlanabilineceği açıkça belirtilmektedir (2224).

\section{SONUÇ}

İD gelişmiş kadınlarda PE ve DŞKE'nin olumlu etkileri olmuştur. Özellikle DŞKE'nin PE'ye oranla ID tedavisinde daha etkili olduğu anlaşılmaktadır. Tedavi edilmediği takdirde önemli sağlık sorunlarına yol açabilen İD'nin erken dönem tedavisinde doğru planlanmış egzersiz müdahalesi önemlidir. Sonuçların doğruluğu açısından daha geniş bir örneklem grubu ile farklı egzersiz şiddetlerinde boylamsal çalışmaların yapılmasına ihtiyaç duyulmaktadır.

\section{Katkı}

$\mathrm{Bu}$ çalışma Hitit Üniversitesi Bilimsel Araştırma Projeleri Birimi tarafından BY019001.15.001 numaralı proje kapsamında desteklenmiştir.

\section{KAYNAKLAR}

1. Pederson A, Haworth Brockman MJ, Clow B, Isfeld H, Liwander A, editors. Rethinking women and healthy living in Canada. 1st ed. Vancouver: British Columbia Centre of Excellence for Women's Health; 2013.

2. Aadahl M, Michael K, Torben J. Associations between overall physical activity level and cardiovascular risk factors in an adult population. Eur J Epidemiol. 2007;22(6):369 78.

3. Després JP, Lamarche $B$, Mauriege $P$, et al. Hyperinsulinemia as an independent risk factor for ischemic heart disease. $N$ Engl J Med Overseas Ed. 1996;334(15):952 8.

4. Levy Marchal C, Arslanian S, Cutfield W. et al. Insulin resistance in children: consensus, perspective, and future directions. J Clin Endocrinol Metab. 2010;95(12):5189 98.

5. Rosenbloom AL. Silverstein JH, Amemiya S. et al. Type 2 diabetes in children and adolescents. Pediatr Diabetes. 2009;10:17 32.

6. Nolan CJ, Peter D, Marc P. Type 2 diabetes across generations: from pathophysiology to prevention and management. Lancet. 2011;378:169 81.

7. Donnelly JE, Blair SN, Jakicic J, et al. ACSM Position Stand. Appropriate physical activity intervention strategies for weight loss and prevention of weight regain for adults. Med Sci Sports Exerc. 2009;412(20):459 71.

8. Khoo J, Dhamodaran S, Chen DD, et al. Exercise induced weight loss is more effective than dieting for improving adipokine profile, insulin resistance, and inflammation in obese men. Int J Sport Nutr Exerc Metab. 2015;25(6):566 75 .
9. Demir H. 1216 yaş erkek badmintoncularda kuvvet antrenmanlarının aerobik güce etkisi. Selçuk Üniversitesi Sağlık Bilimleri Enstitüsü Doktora Tezi. Konya: Selçuk Üniversitesi; 1996.

10. Brown WJ, Nicola WB, Paul JB. Updating the evidence on physical activity and health in women. Am J Prev Med. 2007;33(5):404 11.

11. Zülal A. BTD Araștırma ve Yazı Grubu, Kadın Sağlığı, Bilim ve Teknik TÜBİTAK. 2005;(Eylül Sayısı):2 3.

12. Garber CE, Blissmer B, Deschenes MR, et al. American College of Sports Medicine position stand. Quantity and quality of exercise for developing and maintaining cardiorespiratory, musculoskeletal, and neuromotor fitness in apparently healthy adults: guidance for prescribing exercise. Med Sci Sports Exerc. 2011;43(7):1334 59.

13. Karvonen J, Timo V. Heart rate and exercise intensity during sports activities. Sports Med.1988;5:303 11.

14. Pua YH, Peck Hoon O. Anthropometric indices as screening tools for cardiovascular risk factors in Singaporean women. Asia Pac J Clin Nutr. 2005;14(1):74 9.

15. Balkau B, Charles MA. for the European Group for the Study of Insulin Resistance Comment on the provisional report from the WHO consultation. Diabet Med. 1999;16(5):442 3.

16. Motahari Tabari N, Ahmad Shirvani M, Shirzad E Ahoodashty M, et al. The effect of 8 weeks aerobic exercise on insulin resistance in type 2 diabetes: a randomized clinical trial. Glob $J$ Health Sci. 2015;7(1):115.

17. Huffman KM, Slentz CA, Bateman LA, et al. Exercise induced changes in metabolic intermediates, hormones, and inflammatory markers associated with improvements in insulin sensitivity. Diabetes Care. 2011;34(1):174 6.

18. Warburton DE, Nicol CW, Bredin SS. Health benefits of physical activity: the evidence. CMAJ. 2006;174(6):801 9.

19. Carrel AL, Allen DB. School based exercise improves fitness, body composition, insulin sensitivity, and markers of inflammation in non obese children. $J$ Pediatr Endocrinol Metab. 2009;22(5):409 16.

20. Margolis LM, Stefan MP. Optimizing intramuscular adaptations to aerobic exercise: effects of carbohydrate restriction and protein supplementation on mitochondrial biogenesis. Adv Nutr. 2013;4(6):657 64 .

21. Nikseresht M, Agha Alinejad, H, Azarbayjani, MA, et al. Effects of nonlinear resistance and aerobic interval training on cytokines and insulin resistance in sedentary men who are obese. J Strength Cond Res. 2014;28(9):2560 8.

22. Gutin B, Scott 0 . The influence of physical activity on cardiometabolic biomarkers in youths: a review. Pediatr Exerc Sci. 2011;23(2):169 85.

23. Guinhouya BC, Hervé H. Insight into physical activity in combating the infantile metabolic syndrome. Environ Health Prev Med. 2011;16(3):144. 
24. Zanuso S, Jimenez, A, Pugliese, G, et al. Exercise for the management of type 2 diabetes: a review of the evidence. Acta Diabetol. 2010;47(1):15 22. 